\title{
Correction to: The role of hepatic transcription factor cAMP response element-binding protein (CREB) during the development of experimental nonalcoholic fatty liver: a biochemical and histomorphometric study
}

Ashraf K. Awaad ${ }^{1,2,3^{*}}$, Maher A. Kamel ${ }^{2}$, Magdy M. Mohamed', Madiha H. Helmy², Magda I. Youssef ${ }^{4}$, Eiman I. Zaki ${ }^{5}$, Marwa M. Essawy ${ }^{3,6}$ and Marwa G. A. Hegazy ${ }^{1}$

Correction to: Egypt Liver Journal 10, 36 (2020)

https://doi.org/10.1186/s43066-020-00046-8

After publication of the original article [1], the authors became aware of the following errors. These have already been corrected in the original article:

1. In the legend of Fig. 3, "Lobular and periportal cellular infiltrates are seen (thick blue arrows)" has been corrected to read "Lobular and periportal cellular infiltrates are seen (thin green arrows)".

2. In the 'Histological assessment' of the 'Results' section, the duplicated sentence "Histological examination of livers... throughout the study periods" has been deleted.

3. Affiliation number 5 for author Eiman I. Zaki has been corrected from "Histochemistry and Cell Biology Department, Faculty of Medicine, Alexandria University, Alexandria, Egypt" to "Histology and Cell Biology Department, Faculty of Medicine, Alexandria University, Alexandria, Egypt".

\begin{abstract}
Author details
${ }^{1}$ Biochemistry Department, Faculty of Science, Ain Shams University, Cairo, Egypt. ${ }^{2}$ Biochemistry Department, Medical Research Institute, Alexandria University, Alexandria, Egypt. ${ }^{3}$ Center of Excellence for Research in

Regenerative Medicine and Applications (CERRMA), Faculty of Medicine, Alexandria University, Alexandria, Egypt. ${ }^{4}$ Histochemistry and Cell Biology Department, Medical Research Institute, Alexandria University, Alexandria, Egypt. ${ }^{5}$ Histology and Cell Biology Department, Faculty of Medicine, Alexandria University, Alexandria, Egypt. ${ }^{6}$ Oral Pathology Department, Faculty of Dentistry, Alexandria University, Alexandria, Egypt.
\end{abstract}

Published online: 14 December 2020

\section{Reference}

1. Awaad AK et al (2020) The role of hepatic transcription factor CAMP response element-binding protein (CREB) during the development of experimental nonalcoholic fatty liver: a biochemical and histomorphometric study. Egypt Liver Journal 10:36. https://doi.org/10.1186/s43066-020-00046-8

\footnotetext{
The original article can be found online at https://doi.org/10.1186/s43066020-00046-8

* Correspondence: ashrafawaad24@gmail.com

'Biochemistry Department, Faculty of Science, Ain Shams University, Cairo,

Egypt

${ }^{2}$ Biochemistry Department, Medical Research Institute, Alexandria University,

Alexandria, Egypt

Full list of author information is available at the end of the article
}

\section{Springer Open}

( ) The Author(s). 2020 Open Access This article is licensed under a Creative Commons Attribution 4.0 International License, which permits use, sharing, adaptation, distribution and reproduction in any medium or format, as long as you give appropriate credit to the original author(s) and the source, provide a link to the Creative Commons licence, and indicate if changes were made. The images or other third party material in this article are included in the article's Creative Commons licence, unless indicated otherwise in a credit line to the material. If material is not included in the article's Creative Commons licence and your intended use is not permitted by statutory regulation or exceeds the permitted use, you will need to obtain permission directly from the copyright holder. To view a copy of this licence, visit http://creativecommons.org/licenses/by/4.0/. 